\title{
Experimental and Numerical Approaches to Overtopping Levee Breach Effects in a River and Floodplain
}

\author{
Md. Serazul Islam ${ }^{1, ~ *, ~ T e t s u r o ~ T s u j i m o t o ~}{ }^{2}$ \\ ${ }^{1}$ School of Agriculture and Rural Development, Bangladesh Open University, Gazipur-1705, Bangladesh \\ ${ }^{2}$ Department of Civil Engineering, Nagoya University, Nagoya, Japan
}

Email address:

seraz_bou@yahoo.com (Md. S. Islam)

\section{To cite this article:}

Md. Serazul Islam, Tetsuro Tsujimoto. Experimental and Numerical Approaches to Overtopping Levee Breach Effects in a River and Floodplain. American Journal of Civil Engineering. Vol. 3, No. 2, 2015, pp. 31-42. doi: 10.11648/j.ajce.20150302.12

\begin{abstract}
This paper described the results to identify, characterize, and simulate the levee breach effects in a river and floodplain by overtopping. One-side levee model is built in a laboratory experimental flume as well as numerical simulation using sand with proper compaction. An initial condition provided for the overflow breach is considered with partial crest opening. Small-scale laboratory experiments were performed to evaluate the effects of overtopping levee breaching and investigated simultaneous phenomena appears in a river, levee and floodplain, and validated the results with same scale numerical simulations; and the results of both approaches were in conformity. The failure behavior of an earthen levee focuses on the effects of material sizes, river bed slopes and bed variations relative to floodplain. According to the results, the higher bed level brings more rapid propagation of the levee breach and widening with more sediment deposition in the floodplain area as well as river bed degradation in the upstream of the levee breach point may cause further risk of the levee breach during the next flood. Using finer bed materials, river bed deformation and sediment deposition in the floodplain are clearly make differences with coarser materials, also it create the normal flow problem through the river in future.
\end{abstract}

Keywords: Overtopping, Levee Breach, Inundation with Sediment Deposition, Laboratory Experiment, Numerical Simulation

\section{Introduction}

Levees are constructed along water courses to provide protection against floods. The failure of such systems because of natural or manmade hazards can have monumental repercussions, sometimes with dramatic and unanticipated consequences on human life, property and the country's economy. Levee overtopping can be caused when flood waters simply exceed the lowest crest of the levee or if high winds begin to generate significant swells (a storm surge) in the ocean or river water to bring waves crashing over the levee. The top and middle overtopping of a levee are occurred due to wave action and the rising of the water level, respectively [1]. With an increase in urban development behind these levees, the risk to public health and safety from failure has increased. There are a number of mechanisms that would cause a levee to fail. Overtopping, surface erosion, internal erosion, and instabilities within embankment or foundation soils are some of them. While other mechanisms require more time to significantly damage a levee, overtopping and seepage would erode the levee in a relatively shorter time, and the erosion would eventually lead to levee breach and failure. The failures of levees are mostly due to overtopping of the crest or piping [2]. According to Broich (1998), 43\% of the failures are by overtopping and $40 \%$ due to piping [3]. Therefore, it is critical to investigate the breaching process and acquire the ability to assess how quickly a levee would fail due to overtopping.

In recent years, the frequency of abnormal floods in Bangladesh has increased substantially, causing serious damage to lives and property. Mostly, the levee breach disaster occurs in Bangladesh because of huge upstream catchments water and sediment load. Particularly, Bangladeshi river beds are aggrades very quickly due to continuous sedimentation, that changes in the river bed level can be observed during one's lifetime. An another problem is damming of the river, which reduces the power of water flow downstream from the dam, and the sediments carried by the river start to settle down faster on the riverbed; causing the river bed aggradations and in turn reducing the water carrying capacity of the river [4, 5], consequences as their banks an overflow, and the flow causes the levee breach. As for the example, due to the Farakka 
Barrage on the Ganges has already caused tremendous damage to the agriculture, navigation, environment, and hydrodynamic equilibrium in Bangladesh [6-9].

Several studies have been conducted to understand the failure mechanism by overtopping. However, most of the research has been done on non-cohesive materials $[10,11]$. Levee/dam break tests have been performed at different scales in the United States [12, 13], England [14] and Norway [15]. The scale of these tests varies from small laboratory flumes to large scale levee failures. Besides the lack of a complete dynamic similitude between models and prototype levees, experimental observations show similar characteristics and behavior during the breach formation process for similar soil composition [16].

The levee breach study is rare in the available literatures except for few experimental, numerical and field investigation have been conducted by Fujita et al., 1987 [17, 18]; Islam et al., 1994 [19]; Aureli and Mignosa, 2003 [20]; Tsujimoto et al., 2006 [21]; and Shimada et al., 2009, 2010 [22, 23]. In those studies; they investigated levee breach expansion process as well as floodplain sedimentation process but did not consider on the river bed height relative to floodplain and the subsequent phenomena appearing in the river bed and in the floodplain. On the other hand, Islam and Tsujimoto (2012) conducted a numerical study; they investigated breach evolution process and the risk of flood disasters in the low floodplain [24, 25]. The levee breaching phenomena appears not only at levee but also from the river to floodplain, and thus physical experiments are difficult while a numerical approach has not been well developed. In this study, the attempt have taken to conduct small-scale laboratory experiments and same condition numerical analyses using coarse and fine sand with steep and mild river bed slope, respectively. There had some difficulties in measurements during work in the laboratory and thus the numerical simulation is necessary for the conformity of this study. Therefore, the investigation have carried out utilizing both approaches to understand the breaching phenomena on the levee, and to evaluate the risk in the floodplain with different height of river bed to floodplain, various river bed materials and slopes.

\section{Solution Approach}

\subsection{Experimental Set-up and Measurements Procedure}

This section describes the laboratory preparation for the runs with experimental conditions to be maintained for different river bed height, and working procedures to fulfill the aforementioned objectives. The experiments are performed in a $20 \mathrm{~m}$ long, $2.2 \mathrm{~m}$ wide and $1.0 \mathrm{~m}$ deep concrete flume is located in the Hydraulic Engineering Laboratory of Nagoya University. The working section is made of wood and sand, which are $6 \mathrm{~m}$ long and $2.2 \mathrm{~m}$ wide (including river channel, levee, floodplain, and drainage channel). The levee slope is $1: 2$ for both sides, and levee height is $0.15 \mathrm{~m}$ from the floodplain. Same sizes of bed material in the river, levee and floodplain of $\mathrm{d}_{50}=1.00 \mathrm{~mm}$ (Run 1 to Run 3) and $0.13 \mathrm{~mm}$
(Run 4 to Run 6) are used. Relative height of river bed and floodplain is set as follows: Run 1 and Run 4 (low river bed) $\mathrm{z}_{\mathrm{b}}=-5 \mathrm{~cm}$, Run 2 and Run 5 (river bed and floodplain at the same level) $z_{b}=0 \mathrm{~cm}$, and Run 3 and Run 6 (high river bed) $\mathrm{Z}_{\mathrm{b}}=5 \mathrm{~cm}$, respectively. Figure $1(\mathrm{a}-\mathrm{b})$ is a schematic representation of the experiment setup, including the top view and the side view, respectively. In experiments, the inflow discharges (a) is supplied initially into an upstream inlet tank of the river channel from an underground water reservoir by a circulating pump. The fixed bed is made of wood (A, D) and the moving bed $(\mathrm{B}, \mathrm{C}, \mathrm{E})$ is prepared by sand are used to construct the levee and floodplain. Initial breaching point is set at $2.5 \mathrm{~m}$ apart from upstream, and a notch $(\mathrm{H})$ is prepared before starting the experiment. A downstream wall (e) of the floodplain is made of $2 \mathrm{~cm}$ height of the wooden board from the floodplain, and this wall is used to protect the movable floodplain, and as well as it maintained inundation depth into the floodplain. A $5 \mathrm{~cm}$ drainage channel $(\mathrm{G})$ is provided at the downstream of the floodplain. The river inflow and outflow discharge are rectified (b) by using a steel wire, and the inflow water is passed through the river $(\mathrm{F})$ over a rectangular weir (g). In order to keep the river water depth roughly to the uniform flow depth, a wooden weir (sill) (c) is installed at the downstream of the river channel. A wave metre (f) (CHT6-30 made by KENEK Co.) is put in front of a rectangular weir to collect the crest over flow water depth, and in the same way another wave metre (CHT6-40 made by KENEK Co.) is set near the downstream side triangular weir (d). During experiment, a video camera (GZ-HM350-B manufactured by JVC) is placed with moving carriage on top of the levee breach section to record the video footage of breach expansion and overflow by the breach. Levee breach expansion processes as well as topographic changes in the river, levee and floodplain are memorized by using a digital still camera (OptioS1manufactured by PENTAX). Two types of actuators (KMB-150A length $1.60 \mathrm{~m}$ and A30 length $1.0 \mathrm{~m}$ made by THK) along with laser sensor (IL-600 is made by KEYENCE) is placed lateral (Figure 2.a) and longitudinal (Figure 2.b) directions over the working area to survey floodplain topography and longitudinal length of the levee breach.

Before starting the experiment, the working section of the flume is prepared as shown in Figure 2.c, and then a notch $(10 \times 5 \mathrm{~cm})$ is cut to provide the initial breach opening for the overflow experiment. Soil sample is collected from this notch section of the levee and analyzed the degree of compaction; we found it is reached nearly $100 \%$. Then, the inlet and outlet tank is filled with water, and the wave meter reading is set at an initial condition (zero). Inflow discharge is allowed to enter gently in the river section and raised the river flow depth up to notch opening by putting a downstream sill properly. The early placed wave meter data are taken to estimate the inflow and outflow water discharge by using the equation for rectangular [27] and triangular weir [28], respectively. The electronic actuator with laser sensor is fixed with a moving carriage on the working area that is travels over the steel frame on both sides of the flume. During experiment, the longitudinal breach widening with time is measured. The river 
section and the floodplain are drained, and the bed is become dried; then the elevation of the bed is measured using computer-aided laser sensors for each run. The $\mathrm{x}$-axis is the longitudinal direction with $\mathrm{y}=0$ at the top of the levee crest, which is $2.20 \mathrm{~m}$ apart from the upstream end; and the final breach expansion is measured in the test area. The bed level changes in the river channel and in the levee, are measured along 32 longitudinal transects with $3 \mathrm{~cm}$ intervals, start at the center of the river channel $(x=0)$ towards the floodplain. The floodplain topographic changes are measured along 64 laterals transects with $5 \mathrm{~cm}$ intervals are pointed from the left side of the floodplain with $\mathrm{y}=0$ towards the right-side where the floodplain deposition is occurred and $\mathrm{z}$ start from the initial position of the floodplain.

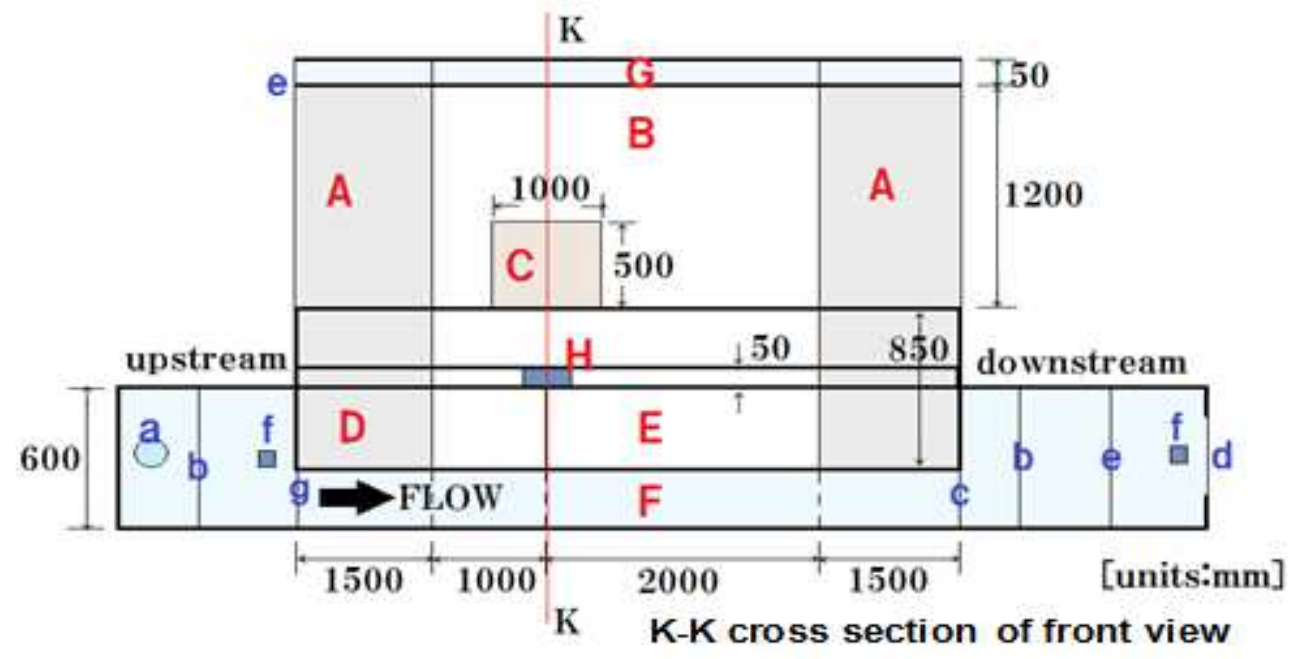

(a)

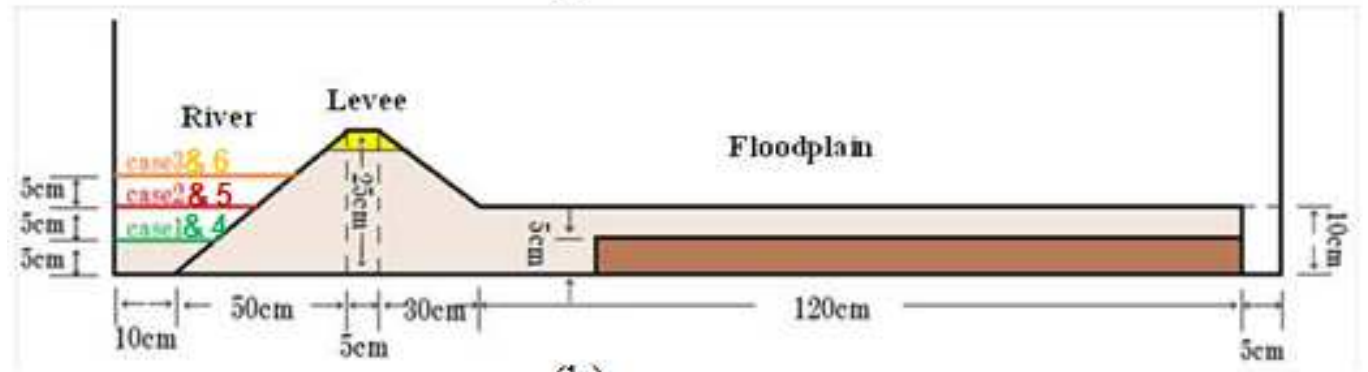

(b)

Figure 1. Experimental setup: (a) top view; (b) side view.

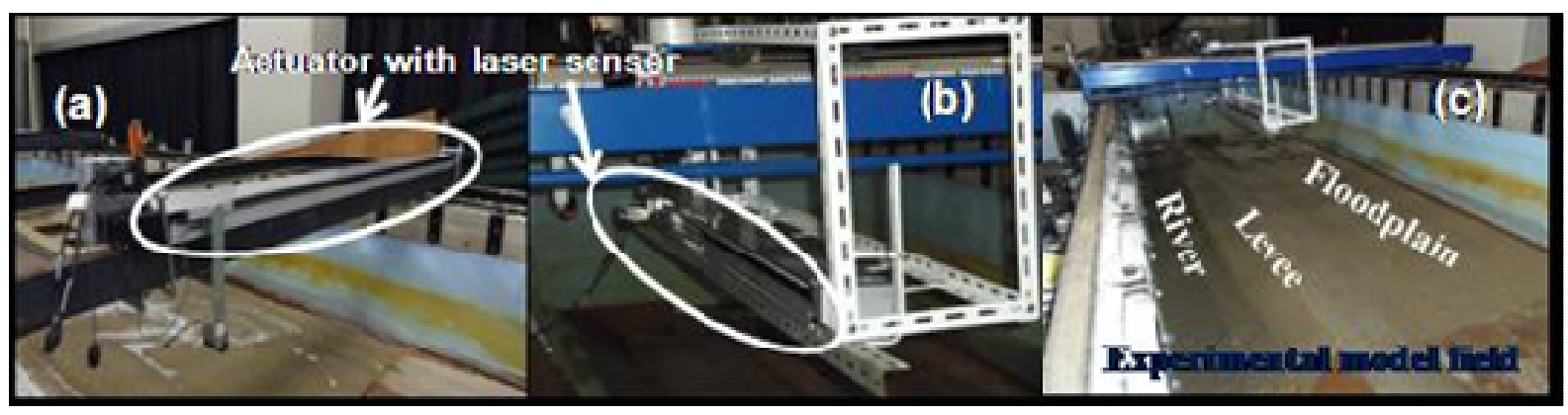

Figure 2. Electronic actuator with computer aided laser sensor (a) lateral, and (b) longitudinal direction; (c) experimental model field.

\subsection{Numerical Set-Up and Measurements Procedure}

The analyses have been made to observe the process appearing in the river, levee and floodplain in a same simulation scheme during the breach. Floodplain inundation with sediment and evolution process of the breach is studied with a numerical model. RIC-Nays (http://i-ric.org/nays/ja/sitmap.html), a two-dimensional (2D) model for the flood flow and morphology is utilized in this study. As for the simulation scheme, the river channel, levee, floodplain and the flow parameters are selected in the conformity with the typical field data. Schematic model area is spatially limited to a part of the actual fields. For all cases of simulation, computation reach is $6.00 \mathrm{~m}$ long and $2.20 \mathrm{~m}$ wide (river channel, levee and floodplain) with a bed slope of river channel is $1 / 500$ (Runs 1 to 3 ) and 1/1000 (Runs 4 to 6) for the coarse and fine bed materials, respectively. Figure 3 depicts one of the model fields for 
simulation. Levee slope is considered as $S_{l}=1: 2$ on both country side and river side. The levee height is taken as $h_{l}=15 \mathrm{~cm}$ from the floodplain and $20 \mathrm{~cm}$ (Runs 1 and 4), $15 \mathrm{~cm}$ (Runs 2 and 5) and $10 \mathrm{~cm}$ (Runs 3 and 6) from the river bed as represent the low, same and high river bed, respectively. Idealized flow and sediment parameters are considered in the computation. Overflow starts from the hypothetical notch on top of the levee as a trigger of the breach, where an initial breach is $10 \mathrm{~cm}$ long $\left(L_{b}\right)$ and $5 \mathrm{~cm}\left(h_{c}\right)$ deep from the top of the levee. Though the river discharge has a hydrograph in general, non-uniform discharge is correspond to the peak is assumed here by putting the downstream sill in the river. The solid boundary wall is imposed on the left-side of the floodplain to protect the direct flow through the floodplain. The inflow discharges $(Q)$ and the corresponding river flow depth before the breach, and the median sizes $\left(d_{m}\right)$ of sediment are chosen, which are shown in Table 1.

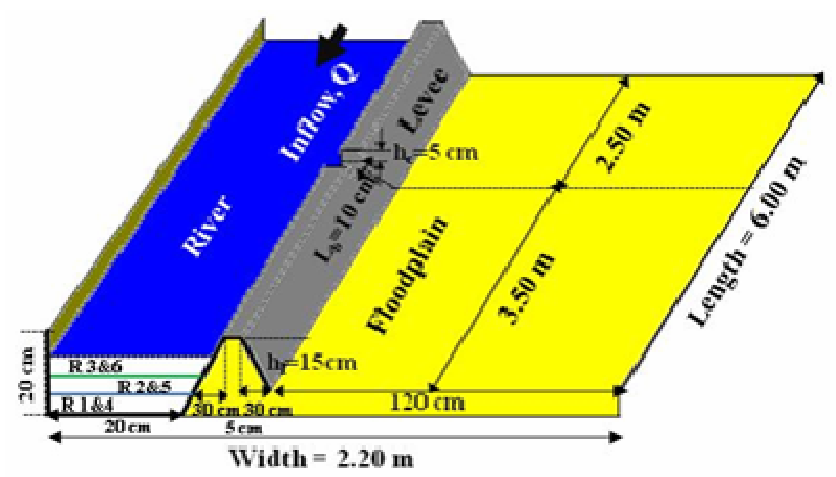

Figure 3. Simulated schematic model fields

Table 1. Condition for all experiments (Same discharge and bed material are used in numerical analysis)

\begin{tabular}{|c|c|c|c|c|c|c|}
\hline \multirow{2}{*}{ Parameters } & \multicolumn{3}{|c|}{ Coarser bed material with steep river bed slope } & \multicolumn{3}{|c|}{ Finer bed material with mild river bed slope } \\
\hline & R 1 & R 2 & R 3 & R 4 & R 5 & R 6 \\
\hline Inflow $Q\left(\mathrm{~m}^{3} / \mathrm{hr}\right)$ & 32.22 & 31.36 & 31.28 & 34.16 & 31.86 & 17.75 \\
\hline River flow depth $h_{0}(\mathrm{~m})$ (Exp.) & 0.16 & 0.11 & 0.08 & 0.16 & 0.11 & 0.06 \\
\hline River flow depth $h_{0}(\mathrm{~m})$ (Num.) & 0.163 & 0.115 & 0.082 & 0.165 & 0.116 & 0.061 \\
\hline Mean velocity $U(\mathrm{~m} / \mathrm{s})$ & 0.16 & 0.19 & 0.23 & 0.18 & 0.22 & 0.22 \\
\hline Bed material size $d_{50}(\mathrm{~mm})$ & 1.00 & & & 0.13 & & \\
\hline Shields number $\tau *$ & 0.20 & 0.13 & 0.01 & 0.67 & 0.62 & 0.31 \\
\hline Sand Reynolds number $R_{e^{*}}$ & 57 & 47 & 40 & 4.88 & 4.66 & 3.31 \\
\hline
\end{tabular}

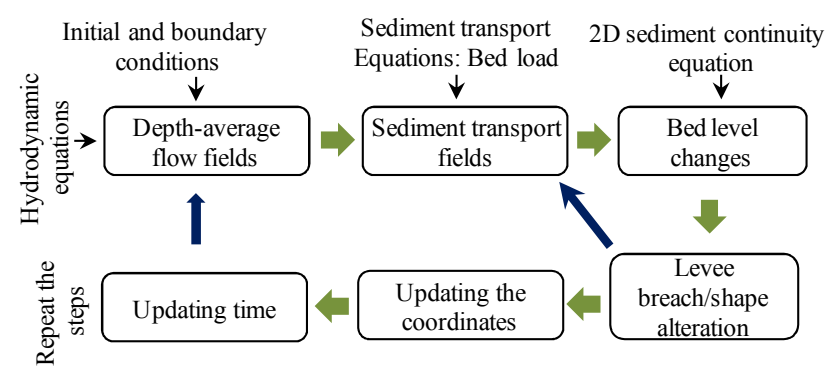

Figure 4. Outline of model computation steps

The flow model is based on the depth-averaged shallow-water equations. The equations expressed in a general coordinate system are solved on the boundary-fitted structured grids using the finite-difference method. Bed-load is calculated by Ashida and Michiue (1972) equations [29]; the effect of cross-gradient [30] and the influence of secondary flow [31] are taken into account. Finally, the bed deformation is determined using the $2 \mathrm{D}$ sediment continuity equation. Equations are solved for the unknown nodal values by an iterative process. The details of the model equations are discussed by Islam and Tsujimoto, 2012b. First, the flow field is computed utilizing initial and boundary conditions; then the sediment transport field is computed, to evaluate the rate of sedimentation, and followed by the bed topography changes. Figure 4 depicts the outline of the simulation steps for computation. The number of cell in the longitudinal and lateral direction is 120 and 44, respectively. In this study, the computation time step is used to 0.002 second, and the model run is made in 10 minutes, when the temporal variations are considerably reduced. By numerical calculation, the breach propagation and the bed topography changes in the river, levee and floodplain can be described [see Figures. 5 (Sim.R1, Sim.R2, Sim.R3) and 7 (Sim.R4, Sim.R5, Sim.R6)], which is realized spatial characteristics of the levee breaching as well as disaster risk in the floodplain during the flood.

\section{Results and Discussion}

In this study, two sets of experiments and numerical analyses were conducted, and each had three runs. For the first set (Run 1 to 3), coarse bed materials with steep river bed slope were taken. The inflow discharges is provided nearly the same both in experiments and numerical throughout the all runs. The river flow capacity is reduced with the increased of the river bed height. Therefore, an initial overflow depth is lifted in case of the higher river bed level (3 cm for Run 3 ) than the lower ones (1 cm for Run 1). However, the second sets of experiments (Runs 4 to 6) have been carried out using fine bed material with mild river bed slope. The inflow discharges are reduced with the increased of the river bed height. The river inflow is higher $\left(34.16 \mathrm{~m}^{3} / \mathrm{hr}\right)$ in Run 4 and lower $\left(17.75 \mathrm{~m}^{3} / \mathrm{hr}\right)$ in the Run 6 . Though, the small amounts of inflow discharges are provided in the Run 6 , which is capable of an overflow levee breach. Considering the above criteria, this research has focused on the levee breaching phenomena and evaluates the disasters risk in the floodplain using both in experiments and numerical approaches. 


\subsection{Levee Breaching Process and Phenomena in River and Floodplain}

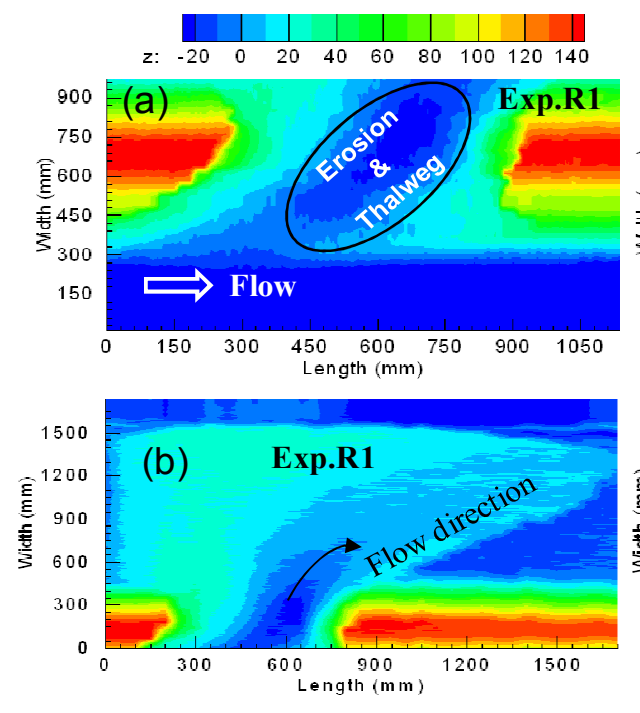

\subsubsection{Coarser Bed Materials and Steep River Bed Slope}
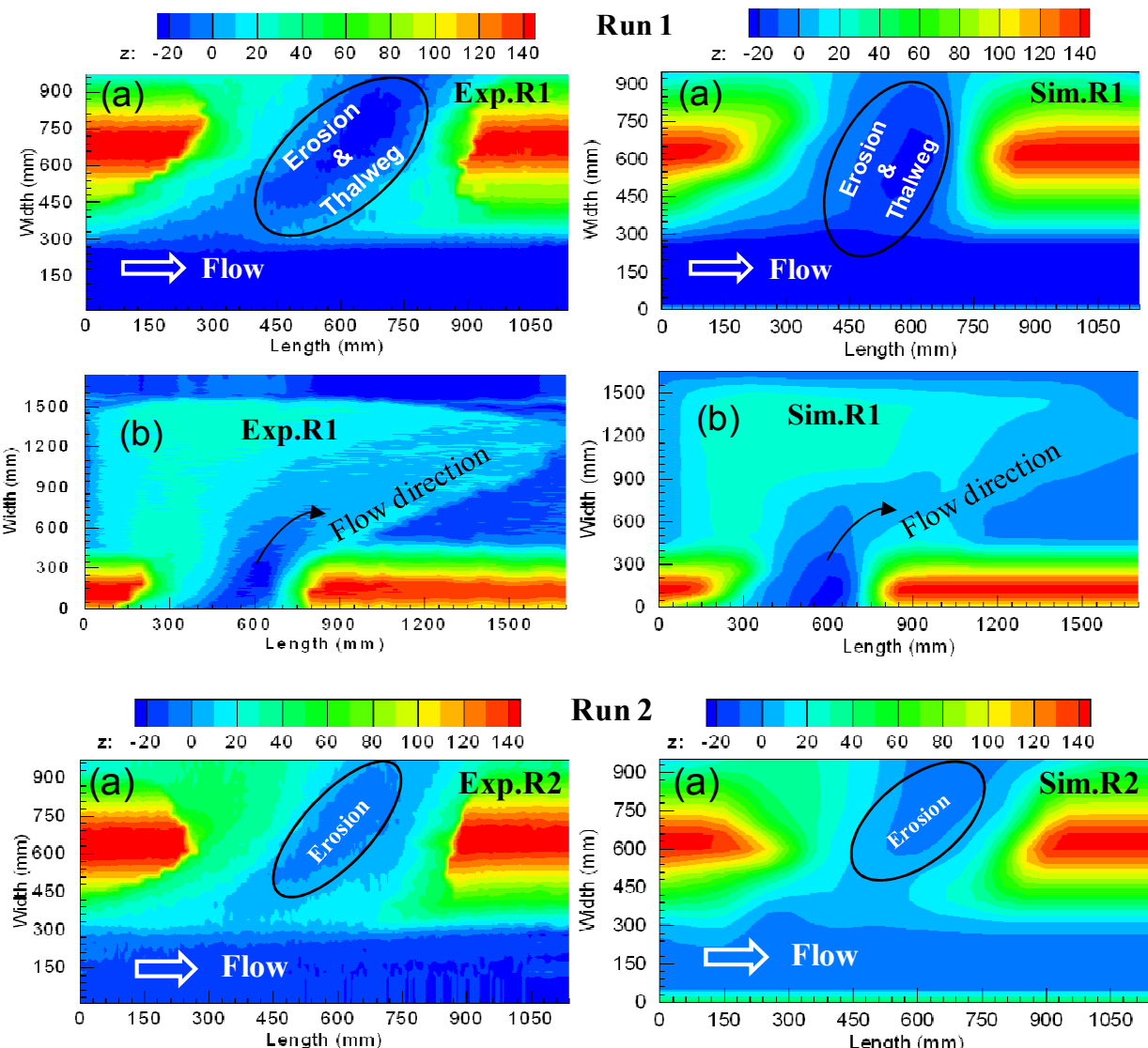

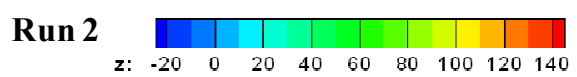
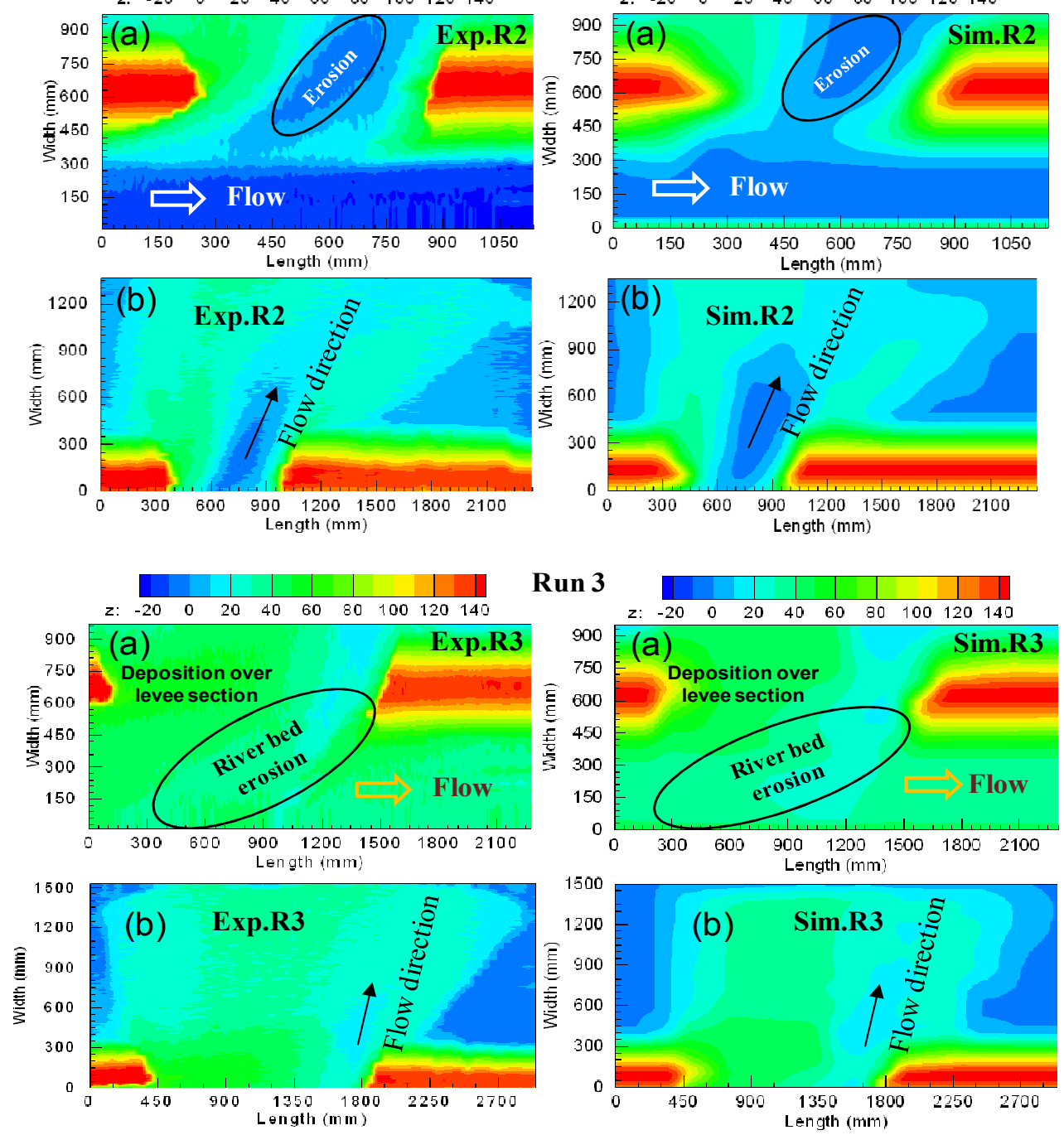

Figure 5. Experiments (Exp.R1, Exp.R2 and Exp.R3) and simulation (Sim.R1, Sim.R2 and Sim.R3) results of bed topographic changes (t=10 min): (a) River channel and levee section; (b) Floodplain. 
The positions of the run are in a top, middle and below for the Run 1, Run 2 and Run 3, individually are depicts in Figure 5. The bed topographic pattern in river and levee section; and the floodplain are denoted by (a) and (b), respectively. After the beginning of overflow, an initial flow passes over the levee crest along with erosion on it near the floodplain, and afterwards, inundation water is spread over the floodplain with vertical erosion from the breach point. Then, the horizontal widening process starts by the collapse of the levee (Exp.R1). The more vertical erosion is observed on the levee section. Due to erosion in the levee as well as near the levee heel, a thalweg is formed along the flow direction from the river to the floodplain. Deposition pattern in the floodplain is smooth, because of coarse bed material, and it indicated that the flow is passes to the right-side direction in the floodplain (Exp.R1, Sim.R1).

In the Run 2, almost same nature of the erosion process appears initially; subsequently, the erosion process comes forward to the heel (inside edge of levee base at river side) of the levee section, and the levee material is washed out, then the horizontal widening process starts, but the rate is slower

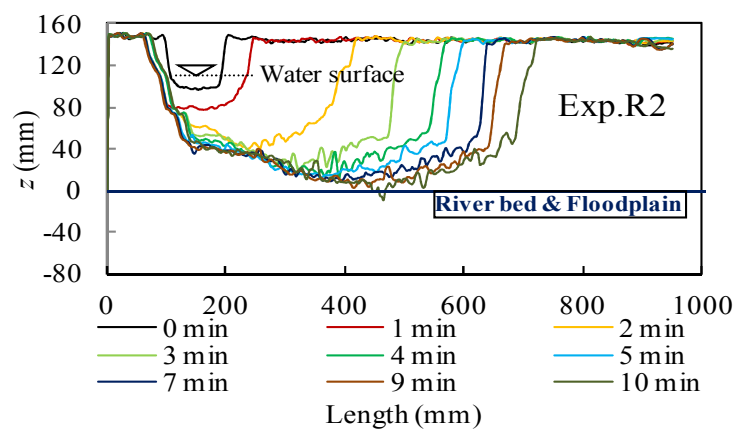

(a)

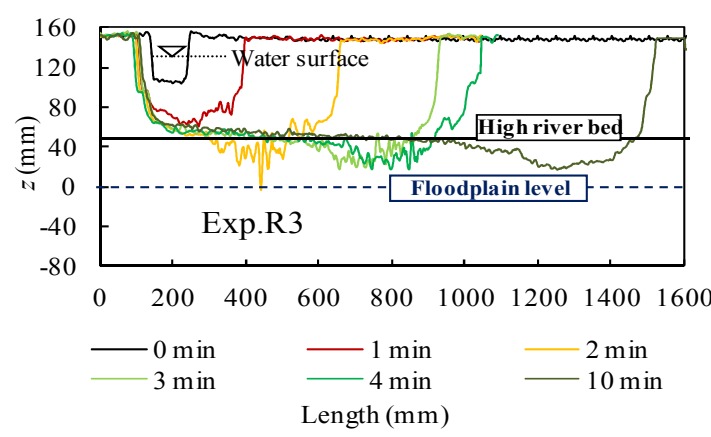

(b)

Figure 6. Longitudinal breach evolution processes of levee with time both in experiment and simulation: (a) Run 2 (Exp.R2, Sim.R2); and (b) Run 3 (Exp.R3, Sim.R3).

The longitudinal levee breach propagation along the river with time for the Run 2 and Run 3 both in experiments and simulation are shown in Figure $6(a, b)$. In the early stage of overflow, the levee breach is progress towards both in the vertical, and in the horizontal direction along the downstream of the levee. Then, the sudden breach widening process is occurred in the longitudinal direction of the levee. After that,

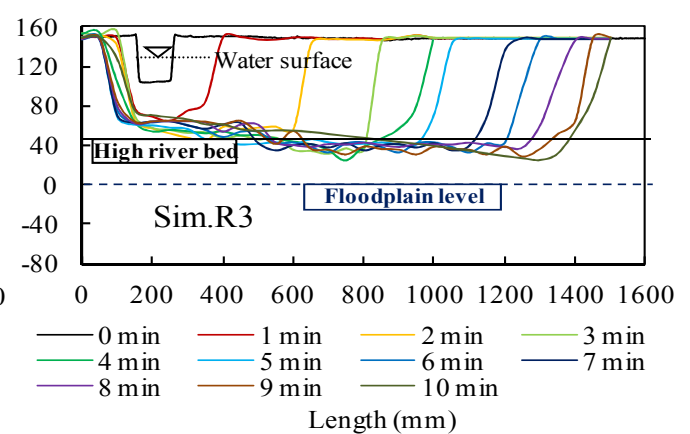

than the Run 1 (Exp.R2). A little erosion is observed on the levee section. The deposition pattern in the floodplain is exposed that the flow is moved all over the floodplain and had a little tendency to the right-side in the floodplain. The floodplain deposition thickness is observed high towards both sides of the flow direction (Exp.R2, Sim.R2).

Whereas in the Run 3, though the initial nature of the erosion is the same as Run 1 and Run 2, but the process is very quick, due to the large amount of inflow discharge, which provide high overflow depth and the level differences between the river beds to floodplain. The levee breach widening process starts in the horizontal direction with the higher rate than the other two runs (Exp.R3). The erosion is observed in the downstream side of the levee along with in the river bed. The early breach levee section is deposited by the eroded material from the levee section and the river bed. The sedimentation thickness in the floodplain is more than the Run 1 and Run 2. The higher bed level is more dangerous as because of the river bed deformation appears, and the bed material is eroded and deposited on the floodplain by the breach (Exp.R3, Sim.R3).

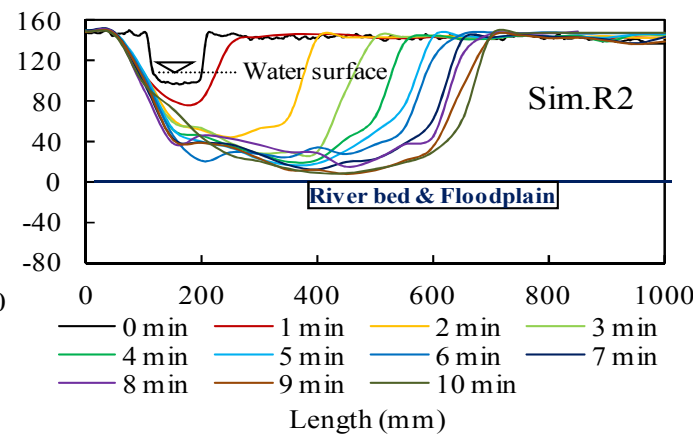

Length $(\mathrm{mm})$

the breach widening process is slow, not only in the horizontal but also in the vertical direction (Exp.R2, Sim.R2). For the Run 3 (Exp.R3 and Sim.R3), the nature of the early erosion process is almost same as the Run 2. However, the horizontal breach widening is rapid, and the vertical erosion process is slow as compared to the Run 2. The total length of the breaches is double than the Run 2 . 


\subsubsection{Finer Bed Materials and Steep River Bed Slope}

In Figure 7; for the Run 4, the initial flow passes straight with the downstream of the floodplain, and then the erosion process starts in the floodplain near the levee toe (outside edge of levee base at the floodplain side). Afterwards, the erosion process comes forward to the centre of the levee with vertical erosion in the levee section, and the horizontal widening process starts by the collapse of the levee (Exp.R4). The large vertical erosion is observed in the levee section with little erosion in the river bed. The ripples and dunes of various dimensions are observed in the floodplain because of the fine bed material. The deposition pattern in the floodplain is indicated that the flow is passes to the right-side direction in the floodplain (Exp.R4 and Sim.R4).

However, in the Run 5, the different nature of the erosion process appears in the levee as compare to Run 4 . The erosion process starts between the levee toe and the centre of the levee, and at the same time the levee section is eroded vertically. Suddenly, the erosion process dominates in the levee section with huge erosion of the levee material. Finally, the horizontal breach widening process starts by loss of the levee section. During the breach widening, the erosion process comes forward to the heel (inside edge of levee base at river side) of the levee as well as in the river bed (Exp.R5). Due to the erosion from the river bed, a thalweg is formed inside the river near the levee along the overflow direction. The river bed material is eroded, and it is deposited on the floodplain by the breach. The deposition pattern in the floodplain is exposed that the flow is moved all over the floodplain and had a little tendency to the right-side in the floodplain (Exp.R5 and Sim.R5).

Whereas, in Run 6, the inflow discharges through the river is smaller than Run 4 and Run 5, but the nature of the initial erosion process is rapid, though the erosion process starts at the levee toe as same as the Run 4. Because of the level difference between the river bed and floodplain, overflow water is quickly passed to the floodplain by the breach with huge vertical erosion in the levee section. Finally, the levee widening process starts in the horizontal direction at the higher rate than the other two runs (Exp.R6). The less vertical erosion is observed in the downstream side of the levee along with erosion in the river bed. In this case also (as like Run 3), the early breach levee section is deposited by the eroded material from the levee section and the river bed. The sedimentation thickness in the floodplain is higher than the Run 4 and Run 5 (Exp.R6 and Sim.R6).
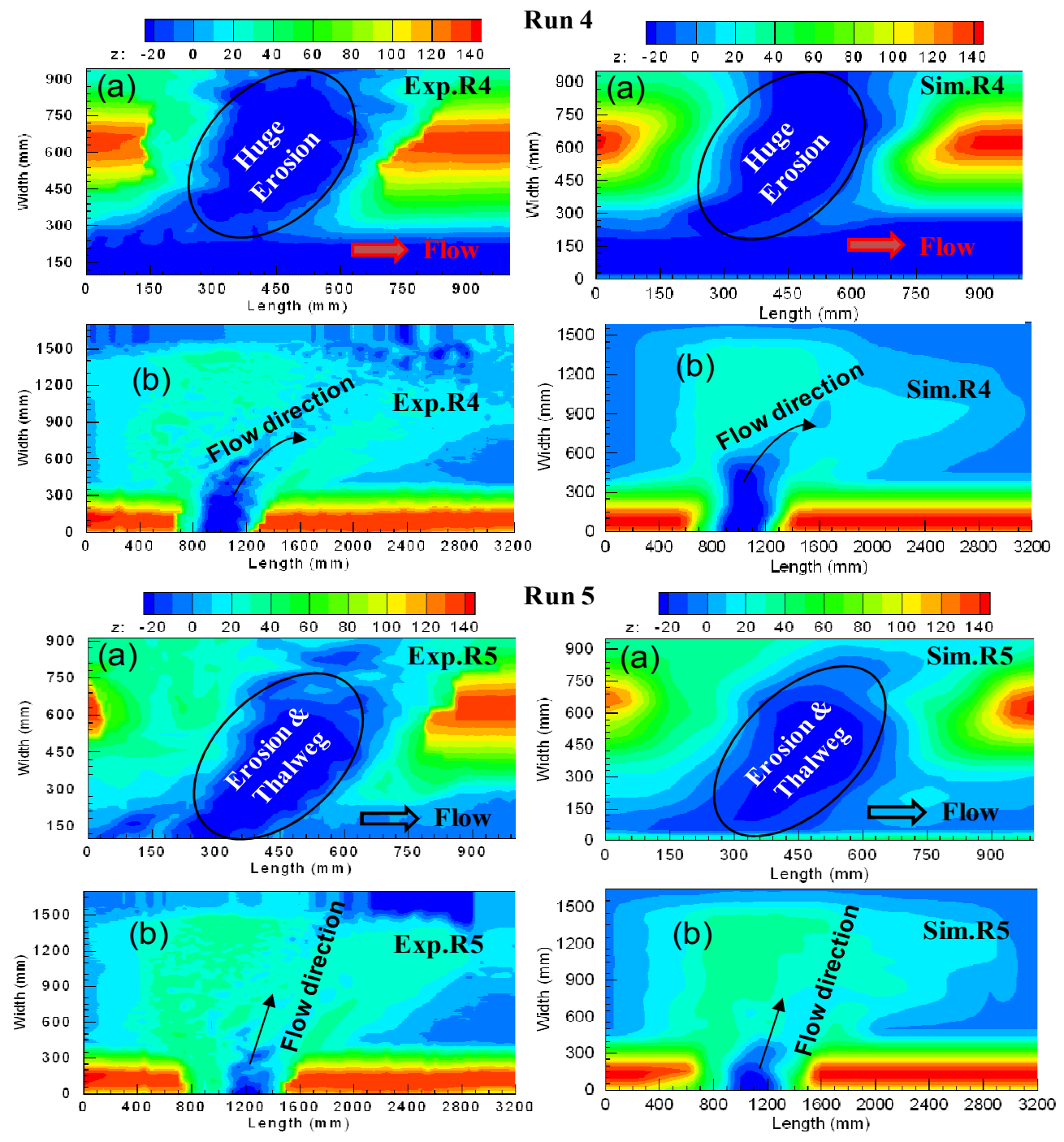

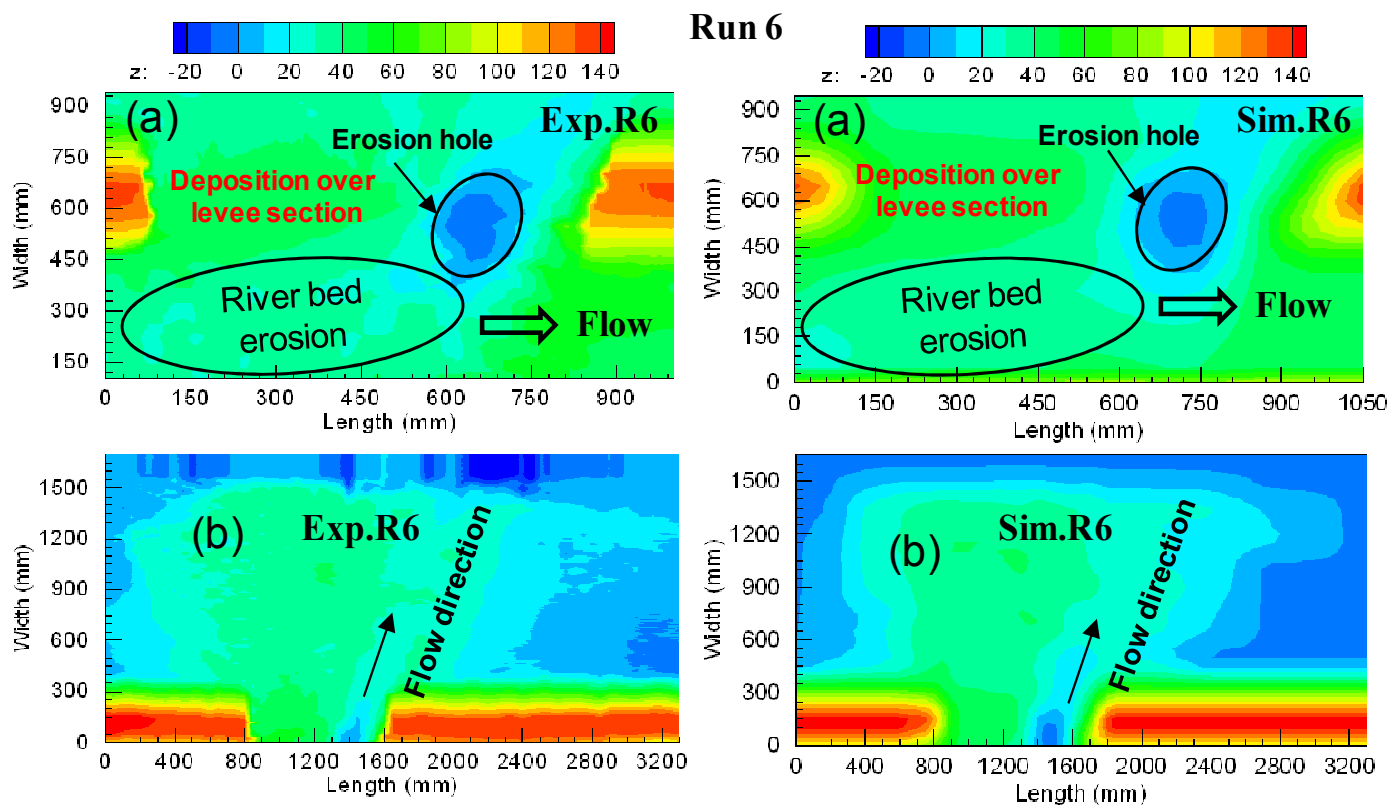

Figure 7. Experiments (Exp.R4, Exp.R5 and Exp.R6) and simulation (Sim.R4, Sim.R5 and Sim.R6) results of bed topographic changes ( $t=10$ min): (a) River channel and levee section; (b) Floodplain.

The longitudinal levee breach propagation along the river with time for the Run 4, Run 5 and Run 6 both in experiments and simulation are shown in Figure 8 ( $a, b$ and $c)$. At short duration, the levee breach is progress towards both in the vertical, and in the horizontal direction along the downstream of the levee. Subsequently, the breach widening process is occurred in the longitudinal direction. After that, the breach widening process is slow, not only in the horizontal but also in the vertical direction (Exp.R4, Sim.R4). In the Run 5 (Exp.R5 and Sim.R5), initially no horizontal erosion is observed

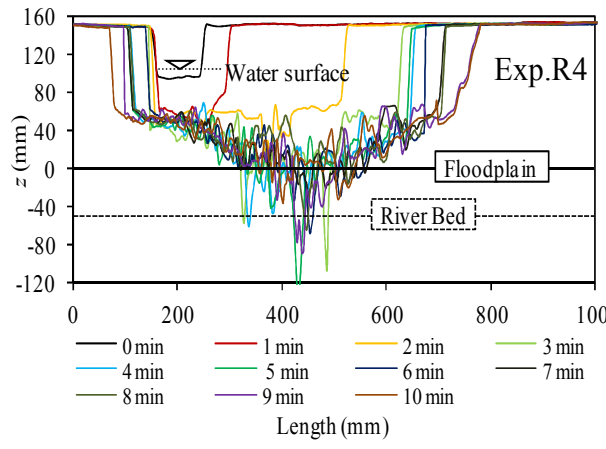

(a)

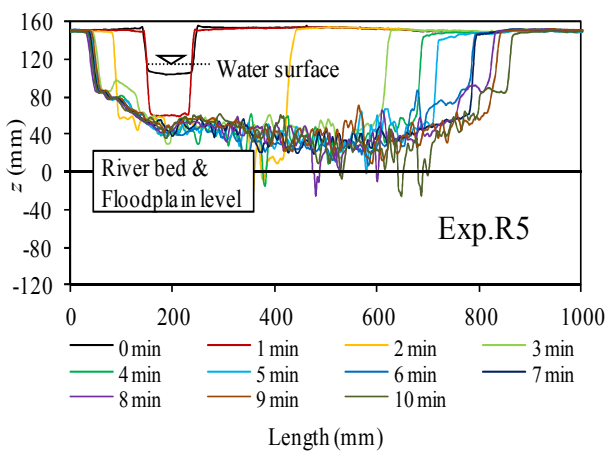

throughout the experiment, but the breach is progress towards both in the vertical and in the horizontal direction in simulation. Then, the breach widening process is same both in experiments and simulation as like in the Run 4. For the Run 6 (Exp.R6 and Sim.R6), the nature of the erosion is nearly equivalent as the Run 5. Even though, the horizontal breach widening process is rapid, and the vertical erosion process is slow as compared to the Run 4 and Run 5. The total length of the breaches is more than the Run 1 and near about same as the Run 2.
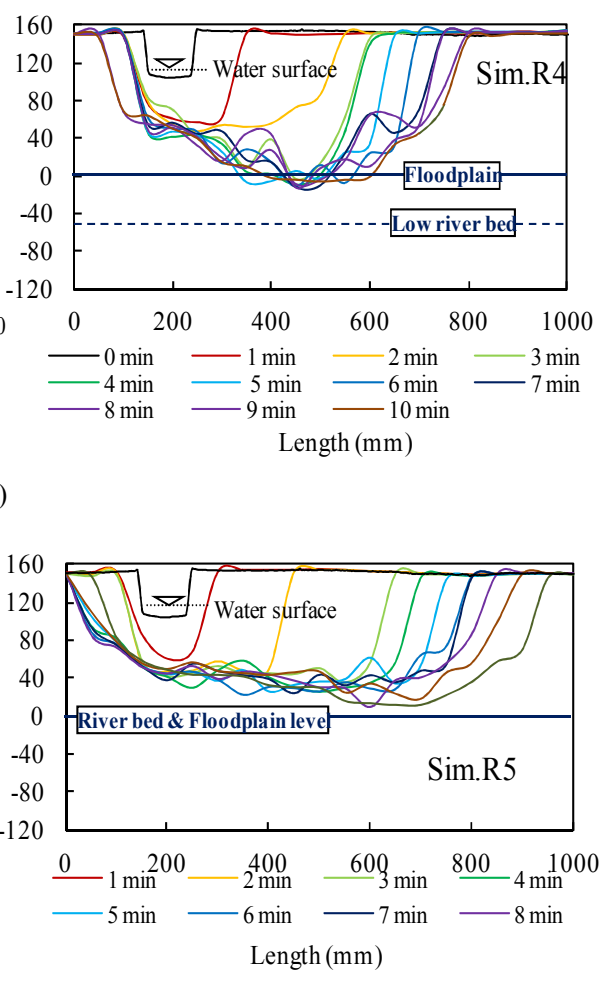

(b) 

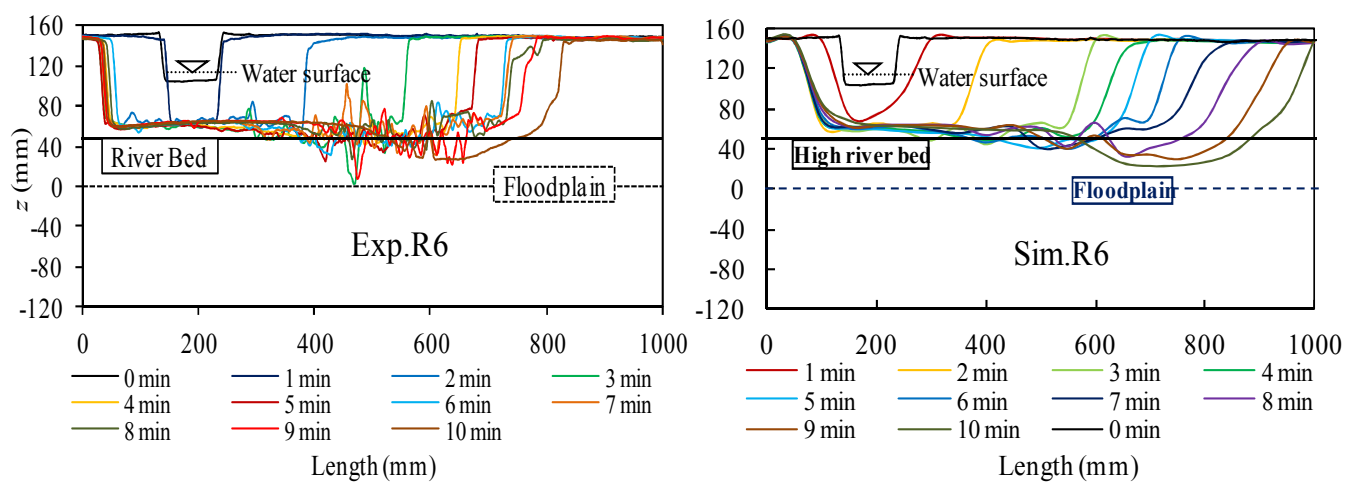

(c)

Figure 8. Longitudinal breach evolution processes of levee with time both in experiment and simulation: (a) Run 4 (Exp.R4 \& Sim.R4); (b) Run 5 (Exp.R5 \& Sim.R5); and (c) Run 6 (Exp.R6 \& Sim.R6).

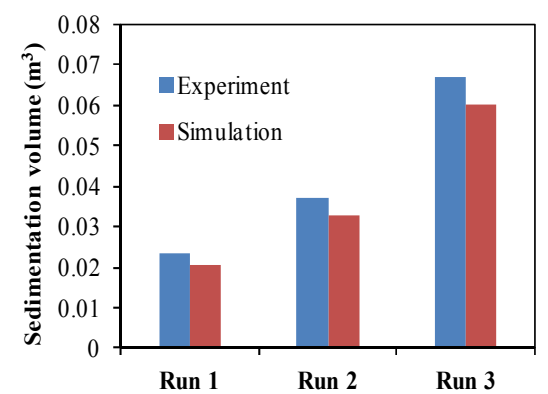

(a)

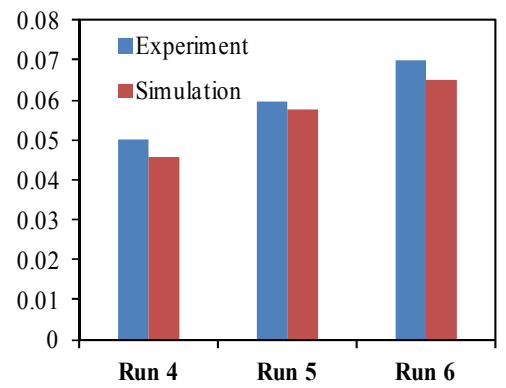

(b)

Figure 9. Comparisons of the volume of the floodplain sedimentation both in experiments and simulation Runs 1 to 6: (a) Coarse bed material and steep slope; (b) Fine bed material and mild slope.

Comparisons of the volume of the floodplain sedimentation at different river bed height are depicted in the Figure 9 (a-b) for both in the experiment and simulation. The sedimentation is less at the low river bed (Run 1, Run 4) as compare to the high river bed (Run 3, Run 6) level. The floodplain sedimentation is increased with increased to the river bed level, and the rate is more in the finer bed material due to the huge vertical erosion from the levee section and the river bed. It also shows that the higher river bed (Runs 3 and 6) with finer bed materials has the high risk of flood disasters in the floodplain considering with the sedimentation in the floodplain.

\subsection{Differences in Levee Breach by River Bed Height Relative to Floodplain}

The comparisons of the final length of the breach widening at different runs for both in the experiments and simulation are

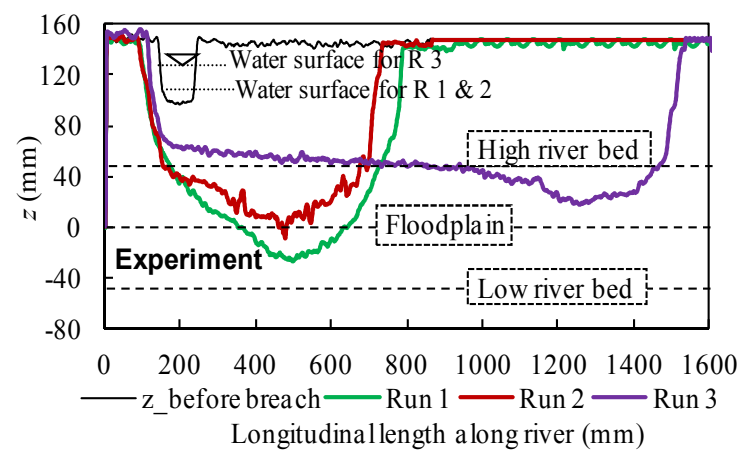

shown in the Figure 10 (a-b). The horizontal lengths of the widening are less in the Run 1 and Run 2 than in Run 3, but the vertical erosion is more in the Run 1 and Run 2. However, the larger widening is seen in the Run 6 as compare to the Run 4 and Run 5 but the vertical erosion is more in the Run 4 and Run 5. In case of the higher river bed with coarser material (Run 3), the horizontal widening is almost double than the lower and same river bed conditions. It happens due to the high river inflow with more overflow depth, and possesses the less bonding effect between the coarser particles. The horizontal widening is longer; it means the more amount of inundation flow passes to the floodplain along with sediment outflow by the breach. It can be concluded that, the higher river bed with coarser bed materials has the high risk of flood disasters in the floodplain.

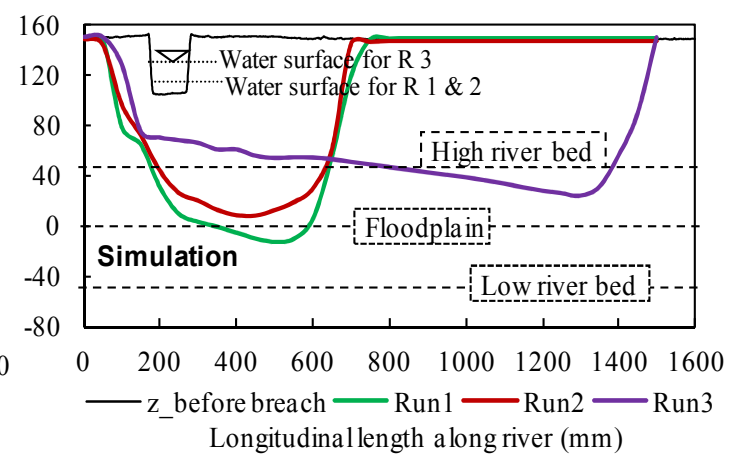



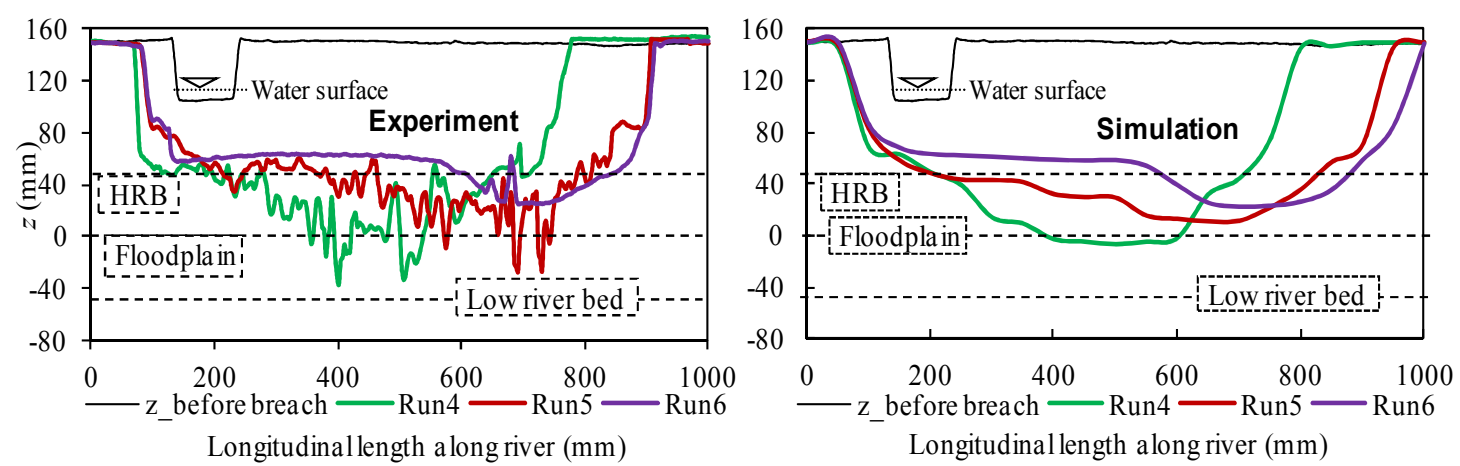

(b)

Figure 10. Comparisons of the final longitudinal lengths of breach along the river for experiments and simulation ( $t=10$ minutes): (a) Runs 1 to 3; and (b) Runs 4 to 6.

\subsection{River Bed Changes Accompanying Levee Breach}

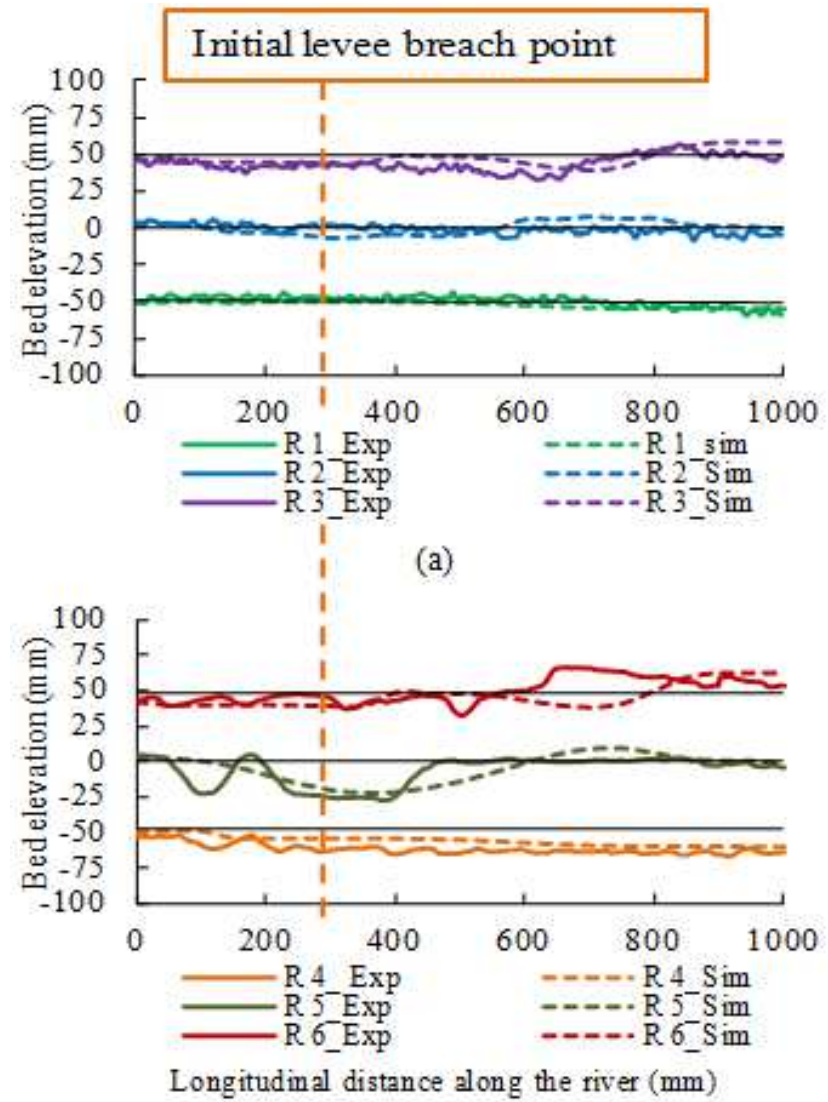

(b)

Figure 11. Comparisons of river bed variations along the river for experiments and simulation: (a) Runs 1 to 3; and (b) Runs 4 to 6.

The river bed deformation comparisons at different relative heights of river bed to floodplain are depicted in Figure 11 (a-b). Both in the experiments and simulation, for coarser bed material, the higher rates of changes are observed in the Run 3, as compared to the Run 1 and Run 2. Nevertheless, the overall deformation rate is more in the Run 5 and Run 6 . Using finer bed material with the same and high river bed level are dangerous as because of more bed deformations are seen. The levee breaches with the high river bed has the problem, not only in the rapid flow propagation with the larger amount of sediment outflow to the floodplain by the breach but also the river bed variation is remarkable, which brings further risk of the levee breach in the upstream reach across the river. The river bed material is eroded, and it is deposited on the floodplain by the breach as well as in the upstream of the levee breaching point.

\section{Conclusions}

This study have conducted using the different sets of experiments and same scenario numerical analyses, to understand the levee breach process and evaluates the risk in the floodplain with considering the effect of river bed height, bed material sizes and river bed slopes. The research result showed that the higher river bed not only influences the effect of levee breaching and floodplain deposition, but also it has unlike characteristics in the river bed variation using different bed materials. The overtopping levee breach study in this research was not cover with any vegetation. The conclusion can be drawn as follows:

1. Though there have some discrepancies between the experiments and same condition numerical analyses, both results showed reasonably good agreement.

2. In coarser bed material, the erosion process starts mainly on the levee crest, and the breach is progress by the washout of the levee material with flow; whereas to use finer bed material the different breach phenomena with huge vertical erosion in the levee along with more river bed deformation appears.

3 . In coarser bed material, the higher river bed is exposed to levee breach with higher overflow depth and thus the widening rate of the levee breach is more rapid and inundation with more sediment volume to the floodplain not only from the levee but also from the river bed as compared to the finer bed material as well as to the lower and the same river bed height.

4. Using finer material, both in the same and the high river bed level, the river bed deformation is remarkable and the bed material is deposited not only in the floodplain but also into the downstream of river, which has the problem for the normal flow through the river in the future. 
5. Furthermore, the levee breach with higher river bed is risky both in coarser and finer bed material, because of the rapid breach widening with more inundation and sediment outflow to the floodplain by the breach as compared to the lower river bed due to a difference to the level between the river bed to floodplain.

\section{Acknowledgments}

The authors are grateful to MEXT, Japan for the financial support required in the study. They wish to thank Dr. T. TASHIRO, Mr. YOSHIIKE and other students of the Hydraulic Engineering Laboratory of Nagoya University for their assistance during experiment setup and data measurements.

\section{References}

[1] Simm, J. and Wallis, M. (2012) "International guidance on levee" [Online]. Available: http://www.hrwallingford.com/projects/test-project. Date accessed: June 7, 2013.

[2] Singh, V.P. (1996) "Dam-Breach Modeling Technology". Kluwer Academic Publishers, Dordrecht, The Netherlands, 242 pp.

[3] Broich, K. (1998) "Mathematical Modelling of Dam Break Erosion Caused by Overtopping". Proc. of the CADAM Meeting, Munich, Germany.

[4] Khalequzzaman, M. (1994) "Recent Floods in Bangladesh: Possible Causes and Solutions". Natural Hazards, 9: 65-80.

[5] Shalash, G. (1982) "Sedimentation in the Aswan High Dam Reservoir”. Hydrobiology, 92: 623-629.

[6] Shahjahan, M. (1983) "Regional Co-operation in the Utilization of Water Resources of the Himalayan Rivers". In, Zaman, M. (ed.) River Basin Development: Dublin, Tycooly International Publishing Ltd., pp. 114-130.

[7] Siddiqui, M.F. (1983) "Management of River System in the Ganges and Brahmaputra Basin for Development of Water Resources”. In, Zaman, M. (ed.) River Basin Development: Dublin, Tycooly International Publishing Ltd., pp. 137-149.

[8] Broadus, J., Milliman, J. and Edwards, S. (1986) "Rising Sea Level and Damming of Rivers; Possible Effects in Egypt and Bangladesh". In, Proc. of United Nations Environments Programme and the U.S. Environmental Protection Agency: Effects of Change in Stratospheric Ozone and Global Climate. New York, 4: 165-189.

[9] Khalequzzaman, M. (1989) "Environmental Hazards in the Coastal Areas of Bangladesh: a Geologic Approach (summary)". In, S. Ferraras and G. Pararas-Carayannis (eds.), Natural and Man-Made Hazards, Proc. of the International Conference on Natural and Man-Made Coastal Hazards, August 14-21, Ensenada, Mexico, pp. 37-42.

[10] Visser, P.J., Zhu, Y. and Vrijling, J.K. (2006) “Breaching of Dikes". Proc. of the 30th Conf. Coastal Eng., San Diego, USA, pp. 2893-2905.
[11] Chinnarasri, C., Tingsanchali,, T., Weesakul, S. and Wongwises, S. (2003) "Flow Patterns and Damage of Dike Overtopping". Intl. J. of Sediment Research, 18 (4): 301-309.

[12] Hanson, G.J., Cook,K.R., and Britton, S.L. (2003). “Evaluating Erosion Widening and Headcut Migration Rates for Embankment Overtopping Tests". ASAE International Meeting, Las Vegas, Nevada, USA.

[13] Sharif, Y. A. (2013) "Experimental study on Piping failure of earthern levee and dams". [Unpublished $\mathrm{PhD}$ Dissertation], Accepted by the Collage of Engineering and Computing, University of South Carolona, USA. 73 pp.

[14] Hassan, M., Morris, M. and Hanson, G. J. (2004) "Breach Formation: Laboratory and Numerical Modeling of Breach Formation". Proc. of the Annual Conference of the ASDSO, Phoenix, Arizona (in CD-ROM).

[15] Kjetil, A. V., Lovoll, M.A., Hoeg, K, Morris, J., Hassan, M. and Hanson G. (2004) "Physical Modeling of Breach Formation; Large Scale Field Tests". Proc. of the Annual Conference of the ASDSO, Phoenix, Arizona, (CD-ROM)

[16] Hanson, G. J., Temple, D.M., Morris, M. and Hassan, M. and Cook, K. (2005) "Simplified Breach Analysis Model for Homogeneous Embankments: Part II, Parameter Inputs and Variable Scale Model Comparisons". 25th USSD Annual Conference: Technologies to Enhance Dam Safety and the Environment, United States Society on Dams, U.S.A., pp. 163-174.

[17] Fujita, Y. and Tamura, T. (1987a) "Enlargement of Breaches in Flood Levee on Alluvial Plains". J. of Natural Disaster Science, 9 (1): 37-60.

[18] Fujita, Y., Muramoto, Y. and Tamura, T. (1987b) "On the Inflow of River Water and Sediment due to Levee Breach". Annual disasters prevention research Institute, Kyoto University, 30 (2): 527-549 (in Japanese).

[19] Islam, M. Z., Okubo, K. and Muramoto, Y. (1994) "Embankment Failure and Sedimentation over the Flood Plain in Bangladesh: Field Investigation and Basic Model Experiments". J. of Natural Disaster Science, 16 (1): 27-53.

[20] Aureli, F. and Mignosa, P. (2001) "Comparison between Experimental and Numerical Results of $2 D$ Flows due to Levee-Breaking”. XXIX IAHR Congress Proceedings, Theme C, September 16-21, Beijing, China.

[21] Tsujimoto, T., Mizoguchi, A. and Maeda, A. (2006) "Levee Breach Process of a River by Overflow Erosion". River flow 2006, Fluvial Hydraulics, Proceedings of IAHR Symposium, Lisbon, Taylor \& Francis, pp. 1547-1555.

[22] Shimada, T., Watanabe, Y., Yokoyama, H. and Tsuji, T. (2009) "An Experiment on Overflow-Induced Cross-Levee Breach at the Chiyoda Experimental Channel". River, Coastal and Estuarine Morphodynamics, 1: 475-481 (in Japanese).

[23] Shimada, T., Hirai, Y. and Tsuji, T. (2010) "Levee Breach Experiment by Overflow at the Chiyoda Experimental Channel". $9^{\text {th }}$ Intl. Conference on Hydro-science and Engineering, IAHR August 2- 5.

[24] Islam, M.S. and Tsujimoto, T. (2012a) "Comparisons of Levee Breach and Successive Disasters in Floodplain between Bangladesh and Japan". Procedia Engineering, Elsevier publication, 28: 860-865. 
[25] Islam M. S. and Tsujimoto, T. (2012b) "Numerical Approach to Levee Breach as a Key of Flood Disasters in Low Land". Int. J. of Civil Engineering, 4 (1): 23-39, India.

[26] Iwagaki, Y. (1956) "Hydro-dynamical Study on Critical Tractive Force". Transactions of the Japan Society of Civil Engineers, 41:1-21(in Japanese).

[27] Itaya, S. and Tejima, T. (1951) "Weir Flow Formula of a Rectangle with a basis of Reebok's Formula". Proc. of the Society of Mechanical Engineers, 17 (56): 5-7 (in Japanese).

[28] Kurokawa, H. and Fuchizawa, T. (1942) "Formula of Triangular Weir Flow". Proc. of the society of Mechanical Engineers, 7 (27), 5 (in Japanese).
[29] Ashida, K and Michiue, M. (1972) "Study on hydraulic resistance and sediment transport rate in alluvial stream". Transactions, JSCE, 206: 55-69 (in Japanese).

[30] Hasegawa, K. and Yamaoka, S. (1980) "The Effect of plane and bed forms of channels upon the meander development". J. of Hydraulic, Coastal and Environmental Engineering, JSCE, 29: 143-152 (in Japanese).

[31] Engelund, F. (1974) "Flow and Bed Topography in Channel Bend". J. of Hydraulic Division, ASCE, 100(HY11): 1631-1648. 